\title{
Evaluation of powdered $0.5 \%$ chlorhexidine acetate-based postmilking teat dip compared with a foamed $1 \%$ iodine-based postmilking teat dip under cold weather conditions in northern New York
}

\author{
K. M. Morrill, ${ }^{1 *}$ J. C. Scillieri Smith, ${ }^{1} \dagger$ H. M. Dann, ${ }^{2}$ H. M. Gauthier, ${ }^{2}$ and C. S. Ballard ${ }^{2}$ \\ ${ }^{1}$ North Country Regional Ag. Team, Cornell University, Ithaca, NY 14853 \\ ${ }^{2}$ William H. Miner Agricultural Research Institute, Chazy, NY 12921
}

\section{ABSTRACT}

The objective of this trial was to compare a powdered $0.5 \%$ chlorhexidine acetate-based postmilking teat dip with a foamed $1 \%$ iodine-based postmilk teat dip during winter on clinical mastitis, subclinical mastitis (somatic cell count $\geq 200,000$ cells $/ \mathrm{mL}$ ), linear score, teat skin condition, teat end score for hyperkeratosis, and risk of developing a new intramammary infection (IMI). Holstein cows $(\mathrm{n}=331)$ housed in freestall and tiestall barns on one farm were blocked by pen, parity, lactation stage, and lactation performance. They were assigned randomly to a powdered chlorhexidine postmilking teat dip (PD; Derma Soft n' Dry, IBA Inc., Millbury, MA) or a foamed iodine-based postmilking teat dip (ID; FS-103, IBA Inc.). Treatments were applied for 6 wk starting January 4, 2016, for 3 milkings per day. Milk samples were collected from each quarter at the beginning and end of the trial and analyzed for aerobic culture and somatic cell count. Cows that had a clinical mastitis event during the trial were quarter sampled for aerobic culture at the time of clinical event. Teat skin condition and teat end score for hyperkeratosis were evaluated at the beginning, middle, and end of the trial based on a 3- and 5-point scale, respectively. No treatment difference was observed for linear score or teat skin condition. Teat end score was greater for ID cows compared with PD cows (2.72 vs. 2.77 ) at the conclusion of the trial. At the beginning of trial 102 PD quarters and 129 ID quarters had an IMI identified on aerobic culture, $402 \mathrm{PD}$ and 457 ID quarters cultured negative, and $109 \mathrm{PD}$ and 125 ID samples were classified as "no significant growth." At the conclusion of the trial, 129 PD and 101 ID quarters had an IMI. Use of PD resulted in a greater risk for developing a new IMI, based on bacteriological culture,

Received July 10, 2018.

Accepted November 8, 2018.

*Corresponding author: kmm434@cornell.edu

†Current Address: New York State Department of Agriculture and Markets, Division of Animal Industry, Albany, NY 12235. at the conclusion of the trial as compared with ID (relative risk $=1.51$; confidence interval: 1.10-2.07). Additionally, use of $\mathrm{PD}$ resulted in a greater risk as compared with ID of coagulase-negative staphylococci (relative risk $=1.5$; confidence interval: $1.10-2.25)$ and Staphylococccus aureus (relative risk $=2.30$; confidence interval: 1.04-5.07) to be present at the conclusion of the trial. In conclusion, use of PD led to a lower teat end score, an increase in new IMI, and an increased risk of coagulase-negative staphylococci and Staph. aureus compared with ID after 6 wk of product use.

Key words: mastitis, linear score, teat dip, postdip

\section{INTRODUCTION}

Mastitis is the most frequent disease of dairy cows and has well-recognized detrimental effects on animal wellbeing and dairy farm profitability. Teat dipping (pre- and postmilking) remains a widely used management practice in the dairy industry to prevent and control mastitis pathogens at the time of milking (Ruegg, 2012). Premilking teat dipping is essential for disinfection of the teat skin before milking to reduce the risk of exposing the open teat end to environmental pathogens during milking. Postmilking teat dipping is helpful at disinfecting the teat from any contagious pathogens that the cow was exposed to during milking, as well as helping to protect the teat end from environmental pathogens before the teat end closes after the cow leaves the parlor (Pankey et al., 1984). Disinfection of the teat skin after milking helps reduce the spread of mastitis pathogens by killing them before they have the opportunity to colonize in the mammary gland (Neave et al., 1969; Vijaya Kumar et al., 2012). Numerous pre- and postmilking teat disinfection products exist, and several publications have documented the effectiveness of these products in preventing IMI in dairy cows (Oliver et al., 2001; Hillerton et al., 2007; Ceballos-Marquez et al., 2013). The National Mastitis Council has published a bibliography of peer-reviewed research on the efficacy of commercially available teat disinfectants (National Mastitis Council, 2014). 
One of the most effective means of controlling mastitis is postmilking teat dipping with a germicide (Pankey et al., 1984). This protects the teat end for a period after milking, kills pathogens that may be on the teat skin, and minimizes the potential passage of those pathogens. Postmilking teat dipping can reduce new infections by $50 \%$. However, teat dipping must be done routinely at each milking. Postmilking teat disinfectants must have an effective killing action to protect the open streak canal after milking; additionally, they must leave teat skin in good condition (Hemling, 2002; Burmeister et al., 1998). Preservation of healthy teat skin is essential for maintaining its natural defense against infection (Hogan et al., 1990; Mein et al., 2001) because sore, dry, cracked teats may harbor mastitiscausing pathogens (Blowey and Edmondson, 2010).

Winter conditions can lead to rapid dehydration and cracking of teat tissue, thus increasing mastitis risks. During winter months, some farms modify postmilking teat dipping practices to proactively reduce the risk of frostbite in the herd. This practice is more common for farms where cows are less protected from environmental conditions in the barn or along pathways to and from the parlor. Different management changes for postmilking teat dip management include blotting the teat end after postdipping to reduce excess moisture, switching to a different formulation of dip intended for winter, switching to a powder-based dip, or discontinuing dipping completely. Although frostbite is the main concern because it can have implication to the cow's health and longevity in the herd, there may be a longer but subtler effect on the mammary gland and teat health on the farm secondary to extreme temperature fluctuations in winter. Some of the above-mentioned management strategies leave cows at a potentially higher risk for mastitis pathogens, increased SCC, and clinical mastitis events. Teat skin chapping and increased hyperkeratosis of the teat ends can reduce the ability to achieve clean teat ends, increase bacterial colonization of teat ends, and put cows at further risk for mastitis and higher SCC (Pankey et al., 1984; Neijenhuis et al., 2001; Breen et al., 2009).

Some management strategies for protecting teat ends from harsh weather may not be as protective as others, and finding the best strategy will help farms where changes in facilities are not feasible. Changes in postmilking teat dip products can result in a reduction in mastitis prevention, especially for contagious pathogens (specifically Staphylococcus aureus) if alternative winter postmilking teat dip products are not as effective.

Research from 1994, in Idaho, indicated that powdered teat dip was as effective as a $1 \%$ iodine postdip at controlling environmental infections (Goldberg et al., 1994). However, the powdered teat dip was found to increase the risk of contagious mastitis due to Staph. aureus resulting in clinical mastitis. Staphylococccus aureus is still a common mastitis pathogen that is present in many herds in northern New York. Another trial using the same powdered teat dip, and a split udder design, in Iowa (Knutson et al., 2011) reported that use of a powdered teat dip did not result in any difference in teat end scoring or teat skin condition. The Knutson et al. (2011) trial did not provide any bacteriological data or effect of parity on teat health, and neither trial (Goldberg et al., 1994; Knutson et al., 2011) reported any SCC or linear score (LS) data.

The objective of this trial was to compare a powdered teat dip with a foamed iodine-based teat dip during winter on clinical mastitis, subclinical mastitis, teat skin condition (TSC), teat end score for hyperkeratosis (TES), and risk of developing a new IMI.

\section{MATERIALS AND METHODS}

The trial was conducted at the William H. Miner Agricultural Research Institute (Chazy, NY) between January 4, 2016, and February 16, 2016, for a trial duration of $44 \mathrm{~d}$. All experimental procedures involving cows were approved by the William H. Miner Agricultural Research Institute Animal Care and Use Committee (ACUC \#2015AUR11). Cows were housed in a freestall barn with foam mattresses bedded with sawdust, a freestall barn with deep sand bedding, and a tiestall barn with foam mattresses bedded with sawdust. Milking occurred 3 times a day (starting at 0430, 1230, and $2030 \mathrm{~h}$ ) in a double 12 parallel parlor (Xpressway Parallel Stall System, BouMatic, Madison, WI). Cows were milked following National Mastitis Council recommendations, including the routine use of pre- and postmilking teat dip and fore-stripping.

Outside weather data (temperature, wind speed, gust speed, and relative humidity) were collected hourly at The Miner R15 weather station in Chazy, New York. Barn temperature and humidity were recorded with data loggers (HOBO U23 Pro v2 Temperature/Relative Humidity Data Logger, Onset Computer Corporation, Bourne, MA) in the freestall and tiestall areas, every 15 min throughout the duration of the trial.

The trial was conducted as a split-herd trial. Cows were assigned randomly within housing location (i.e., pen or group) by lactation number $(1,2$, or $\geq 3)$ and stage of lactation $(<30 \mathrm{DIM}=$ fresh, 30 to $89 \mathrm{DIM}=$ early, 90 to 179 DIM = middle, and $\geq 180$ DIM = late) to 1 of 2 treatments by a coin flip. The treatments were a powdered $0.5 \%$ chlorhexidine acetate-based teat dip (PD; Derma Soft n' Dry, IBA Inc., Millbury, MA) or a foamed 1\% iodine-based teat dip (ID; FS-103, IBA Inc.). Treatment assignments were identified by col- 
ored leg bands to allow for identification of appropriate postmilking teat dip treatment by the milking personnel. Powdered teat dip was applied using an Ambic Standard Dipper Cup ADC/100 (Ambic Equipment Limited, Oxford, UK). Foamed ID dip was applied using a Foam Boss system (IBA Inc.).

All other management practices on the farm remained unchanged. The milking equipment was checked and serviced before the trial to ensure proper function.

Cows were on treatment for $44 \mathrm{~d}$ (January 4, 2016, to February 16, 2016). This timeframe was selected because it is normally the coldest time of the year in northern New York, and the cows were not enrolled in any other research trials. Aseptic quarter samples were collected on d 1 and 44 to assess IMI; additionally, quarter samples were taken when a cow had a clinical mastitis event (all 4 quarters). Standard culture technique was performed on all samples by Quality Milk Production Services (Canton, NY) according to National Mastitis Council (1999) guidelines for identification of aerobic organisms. Briefly, $0.01 \mathrm{~mL}$ of milk was streaked on trypticase soy agar containing 5\% sheep blood and 1\% esculin (PML Microbiologicals, Mississauga, ON, Canada) and MacConkey's agar (Hardy Diagnostics, Santa Maria, CA) for identification of gram-negative organisms, and plates were incubated aerobically at $37^{\circ} \mathrm{C}$ for 18 to $24 \mathrm{~h}$. After observation of colony morphology and hemolytic patterns, isolates were examined further by means of $3 \%$ potassium hydroxide, Gram staining, catalase and oxidase testing, PathoDx Strep Grouping Latex tests (Thermo Fisher Scientific, Lenexa, KS), and additional biochemical and metabolic evaluations as needed. Diagnosis and confirmation of IMI by culture of a single quarter milk sample was based on standard published definitions (Dohoo et al., 2011). Confirmation of etiologic cause was defined as the isolation of one or more colonies from $10 \mu \mathrm{L}$ of milk for all pathogens except for CNS. For CNS, 2 or more colonies isolated from the sample were needed to establish the presence of an infection. When 2 or more different bacterial pathogens were identified in the same sample, the result was classified as a mixed infection. If 1 nonpathogenic or $\geq 2$ dissimilar nonpathogenic colony types were present in low levels ( 1 to 5 colonies), the culture was defined as having "no significant growth" (i.e., the cow is unlikely to have an IMI; Vasquez et al., 2017). Pathogenic was defined as bacteria known to cause mastitis, and nonpathogenic was defined as the presence of environmental contaminants. Contamination was defined as the isolation of 3 or more different colony types ( $>5$ colonies each) from the milk sample (Vasquez et al., 2017).

In this trial, a new IMI was defined as having a negative culture at the beginning of the trial, but a pathogen was cultured at termination of the trial. Persistent IMI was defined as a positive culture result at the beginning and termination of the trial.

Quarter level SCC was evaluated using flow cytometry (SomaScope, Delta Instruments, Drachten, the Netherlands). Teat end score and TSC were assessed on d 1, 24, and 44 using a categorical scoring system. Teat end condition was evaluated on a 5-point scale, as follows: (1) teat end sphincter is smooth with no evidence of irritation, (2) teat end has a raised ring, (3) teat end sphincter is roughened with slight cracks but no redness is present, (4) teat end sphincter is inverted with many cracks giving a flowered appearance, and (5) teat end is severely damaged and ulcerative with scabs or open lesions (Goldberg et al., 1994). Teat skin condition was evaluated on a 3 -point scale (1: normal/ smooth, 2: dry/slightly rough, 3: cracking/open lesion; Mein et al., 2001; Reinemann et al., 2001; NMC, 2007). Teat evaluation was conducted by the same person at each visit and was performed after the milking unit was removed and before the postmilking teat disinfectant was applied.

Statistical computations were performed using the Statistical Analysis System (version 9.4, SAS Institute Inc., Cary, NC). The final data set used for statistical analyses included 1,321 quarters from 331 cows that were enrolled for the full duration of the trial. All data were evaluated for model assumptions of homogeneity of variance and normality using the Univariate procedure of SAS. Somatic cell count was transformed and analyzed as SCS according to Shook (1993) using the equation: $\mathrm{SCS}=\log _{2}(\mathrm{SCC} / 100)+3$, where $\mathrm{SCC}$ is in units of 1,000 cells $/ \mathrm{mL}$. Somatic cell score is reported using the term LS to be able to compare with other research. Initial DIM was categorized to stage of lactation, where $<30 \mathrm{DIM}=$ fresh, 30 to $89 \mathrm{DIM}=$ early, 90 to $179 \mathrm{DIM}=$ middle, and $\geq 180 \mathrm{DIM}=$ late. Descriptive data (lactation, DIM, milk production, temperature, and humidity) were analyzed using the MEANS procedures and reported as descriptive statistics (mean $\pm \mathrm{SE})$.

Linear score data were analyzed using the MIXED procedure of SAS (version 9.4; SAS Institute Inc., Cary, $\mathrm{NC}$ ) according to the following model:

$$
\mathrm{Y}=\mu+\mathrm{Q}_{\mathrm{i}}+\mathrm{T}_{\mathrm{j}}+\mathrm{S}_{\mathrm{k}}+\mathrm{L}_{\mathrm{l}}+\mathrm{e}_{\mathrm{ijkl}} \text {, }
$$

where $\mathrm{Y}=$ the dependent variable; $\mu=$ the overall mean; $Q_{i}=$ the random effect of quarter within cow i ( $\mathrm{i}$ $=$ left front, right front, right rear, and left rear); $\mathrm{T}_{\mathrm{j}}=$ the fixed effect of $j$ th treatment $\left(\mathrm{j}=\mathrm{PD}\right.$ or ID); $\mathrm{S}_{\mathrm{k}}=$ the fixed effect of kth stage of lactation $(\mathrm{k}=<30,30$ to 89,90 to 180 or $\geq 180$ DIM); $\mathrm{L}_{1}=$ the fixed effect of 
lth lactation number $(1=$ first, second, and third and greater); and $\mathrm{e}_{\mathrm{ijkl}}=$ the residual error.

Teat skin condition data were analyzed using the MIXED procedure of SAS (SAS Institute Inc.) according to the following model:

$$
\mathrm{Y}=\mu+\mathrm{Q}_{\mathrm{i}}+\mathrm{T}_{\mathrm{j}}+\mathrm{S}_{\mathrm{k}}+\mathrm{L}_{\mathrm{l}}+\mathrm{D}_{\mathrm{m}}+\mathrm{TS}_{\mathrm{jk}}+\mathrm{e}_{\mathrm{ijklm}},
$$

where $\mathrm{Y}=$ the dependent variable; $\mu=$ the overall mean; $\mathrm{Q}_{\mathrm{i}}=$ the random effect of quarter within cow i (i $=$ left front, right front, right rear, and left rear); $\mathrm{T}_{\mathrm{j}}=$ the fixed effect of $j$ th treatment $\left(j=P D\right.$ or ID); $S_{k}=$ the fixed effect of kth stage of lactation $(\mathrm{k}=<30,30$ to 89,90 to 179 , or $\geq 180 \mathrm{DIM}) ; \mathrm{L}_{1}=$ the fixed effect of lth lactation ( $\mathrm{l}=$ first, second, and third and greater $)$; $\mathrm{D}_{\mathrm{m}}=$ the fixed effect of $\mathrm{mth}$ day on treatment $(\mathrm{m}=$ $0 \ldots 44) ; \mathrm{TS}_{\mathrm{jk}}=$ the fixed interaction between the jth treatment and the kth stage of lactation; and $\mathrm{e}_{\mathrm{ijklm}}=$ the residual error.

Teat end score data were analyzed using the MIXED procedure of SAS (SAS Institute Inc.) according to the following model:

$$
\begin{gathered}
\mathrm{Y}=\mu+\mathrm{Q}_{\mathrm{i}}+\mathrm{T}_{\mathrm{j}}+\mathrm{S}_{\mathrm{k}}+\mathrm{L}_{1}+\mathrm{D}_{\mathrm{m}}+\mathrm{TS}_{\mathrm{jk}}+\mathrm{TL}_{\mathrm{jl}} \\
+\mathrm{TD}_{\mathrm{jm}}+\mathrm{TSD}_{\mathrm{jkm}}+\mathrm{e}_{\mathrm{ijklm}},
\end{gathered}
$$

where $\mathrm{Y}=$ the dependent variable; $\mu=$ the overall mean; $\mathrm{Q}_{\mathrm{i}}=$ the random effect of quarter within cow $\mathrm{i}$ ( $\mathrm{i}=$ left front, right front, right rear, and left rear); $\mathrm{T}_{\mathrm{j}}$ $=$ the fixed effect of jth treatment $\left(\mathrm{j}=\mathrm{PD}\right.$ or ID); $\mathrm{S}_{\mathrm{k}}$ $=$ the fixed effect of $\mathrm{kth}$ stage of lactation $(\mathrm{k}=<30$, 30 to 89,90 to 179 , or $\geq 180 \mathrm{DIM}) ; \mathrm{L}_{1}=$ the fixed effect of lth lactation $(\mathrm{l}=$ first, second, third and greater $)$; $\mathrm{D}_{\mathrm{m}}=$ the fixed effect of $\mathrm{mth}$ day on treatment $(\mathrm{m}=$ $0 \ldots 44) ; \mathrm{TS}_{\mathrm{jk}}=$ the fixed interaction between the jth treatment and the kth stage of lactation; $\mathrm{TL}_{\mathrm{jl}}=$ the fixed interaction between the jth treatment and the lth lactation number; $\mathrm{TD}_{\mathrm{jm}}=$ the fixed interaction between the jth treatment and mth day on treatment; $\operatorname{TSD}_{\mathrm{jkm}}=$ the fixed interaction between the jth treatment, the kth stage of lactation, and the mth day on treatment; and $\mathrm{e}_{\mathrm{ijklm}}=$ the residual error.

For all models and analysis, the covariance structure of variance components, compound symmetry was used on the subject effect of quarter within cow. Degrees of freedom were calculated using the Satterthwaite option of the MIXED procedure of SAS (SAS Institute Inc.). Least squares means were determined for each treatment.

The FREQ procedure with the CHISQ option of SAS (version 9.4, SAS Institute Inc.) was used to determine the relationship between $\mathrm{PD}$ and ID and the relative risk of an increase in LS, TES, TSC, and change in IMI etiology. Significance was declared at $P \leq 0.05$, a trend was declared at $P \leq 0.1$.

Post hoc power analyses of treatment differences for LS, TSC, and TES means as well as dichotomous bacteriological data (risk of bacterial growth, CNS, and Staph. aureus) at final sampling were performed using the G*Power 3 program (Faul et al., 2007; University of Düsseldorf, Düsseldorf, Germany).

\section{RESULTS}

A total of 331 cows $(\mathrm{PD}=154$; ID $=177)$ representing 1,321 quarters $(\mathrm{PD}=615$; ID $=706)$ were included in the final data set. The difference in cow numbers between treatments was due to cows being dried off or leaving the herd before the end the trial. No cows on the trial left the herd because of IMI. Average lactation number, DIM, and milk production at the start of the trial were not different between treatment groups (Table 1).

Outside, ambient temperature averaged $-6.3^{\circ} \mathrm{C}$ (range $=-28.1$ to 5.2 ; Table 2). A total of $37 \mathrm{~d}$ had an average temperature $\leq 0^{\circ} \mathrm{C}$.

A total of 12,664 observations for temperature and humidity within the barn were recorded. Pen temperatures ranged from -6.6 to $17.1^{\circ} \mathrm{C}$, with a mean value of $5.6^{\circ} \mathrm{C}$. No single day had an average pen temperature $\leq 0^{\circ} \mathrm{C}$. Only 121 pen observations $(0.96 \%)$ had a temperature $\leq 0^{\circ} \mathrm{C}$. The barn only had $1 \mathrm{~d}$ with $6 \mathrm{~h}$ of times having a temperature $\leq 0^{\circ} \mathrm{C}$. Relative humidity within the barn ranged from 35.6 to $100 \%$ with a mean value of $77.0 \%$.

At the beginning of the trial, $83 \mathrm{PD}$ and 62 ID quarters had a SCC $>200,000$ cells $/ \mathrm{mL}$. At the conclusion of the trial, $120 \mathrm{PD}$ and 128 ID quarters had a SCC $>200,000$ cells $/ \mathrm{mL}$. No treatment difference was observed in SCC or LS. At the conclusion of the trial, LS

Table 1. Demographics of trial

\begin{tabular}{lccc}
\hline & \multicolumn{2}{c}{ Treatment $^{1}$} & \\
\cline { 2 - 3 } Cow data & PD & ID & \\
\hline Lactation no. & $(\mathrm{n}=154)$ & $(\mathrm{n}=177)$ & SD \\
Minimum & 2.07 & 2.14 & 1.24 \\
Maximum & 1.00 & 1.00 & \\
DIM & 7.00 & 6.00 & \\
Minimum & 152.06 & 144.31 & \multirow{2}{*}{98.88} \\
Maximum & 2 & 1.00 & \\
Milk (kg/d) & 424 & 446.00 & \multirow{2}{*}{10.69} \\
Minimum & 42.88 & 31.45 & \\
Maximum & 3.63 & 11.79 & \\
\hline
\end{tabular}

${ }^{1} \mathrm{PD}=$ powdered chlorhexidine postdip; ID $=$ foamed iodine-based postdip. Difference in animal numbers between treatment groups is due to some animals being culled or dried off early during the treatment period. 
Table 2. Outside, ambient weather conditions from January 4, 2016, to February 16, 2016

\begin{tabular}{lrrrrr}
\hline Variable & $\mathrm{N}$ & Mean & \multicolumn{1}{c}{$\mathrm{SD}$} & Minimum & Maximum \\
\hline Temperature $\left({ }^{\circ} \mathrm{C}\right)$ & 1,056 & -6.28 & 6.79 & -28.05 & 5.16 \\
Wind speed $(\mathrm{kph})$ & 1,056 & 4.84 & 4.72 & 0.34 & 21.90 \\
Gust speed (kph) & 1,056 & 16.46 & 9.50 & 2.95 & 42.65 \\
Relative humidity (\%) & 1,056 & 61.25 & 24.41 & 20.03 & 94.70 \\
\hline
\end{tabular}

was greater in cows $<30$ DIM $(P<0.001)$ as compared with all other groups (Table 3$)$. A trend $(P=0.09)$ was observed for lactation to have an effect on final LS, with lactation 1 and 2 cows having a lower LS than lactation 3 cows $(2.0941,2.0938$, and 2.0931 , respectively). No treatment by stage of lactation or treatment by lactation interaction on LS was observed.

Similar to LS, no treatment effect was observed on TSC (Table 3); however, TSC improved throughout the trial $(P<0.001 ; 1.40$ vs. 1.29$)$. No treatment by time interaction was observed. Teat skin condition scores were higher for third and greater lactation animals as compared with first and second lactation cows $(P=$ 0.03); however, no treatment by lactation effect was observed. Teat skin condition was greater at the conclusion of the trial for cows receiving PD and 30 to 89 DIM as the start of the trial as compared with all other groups of cows (Figure 1). A total of $75.53 \%$ of PD quarters and $74.50 \%$ of ID quarters had a TSC of 1 at the beginning of the trial, $60.98 \%$ of $\mathrm{PD}$ and $62.32 \%$ of ID quarters had a TSC of 1 at $24 \mathrm{~d}$ and $68.94 \%$ of PD quarters, and $70.96 \%$ of ID quarters had a TSC of 1 at the conclusion of the trial.

There was an effect of treatment on TES $(P=0.01)$ with PD quarters having a lower TES as compared with ID quarters (Table 2). Additionally, there was an effect of time $(P=0.01)$, lactation number $(P=0.05)$, treatment by stage of lactation interaction $(P=0.04$; Figure 2), treatment by lactation number interaction $(P=0.01$; Figure 3$)$, and a trend for a treatment by time interaction $(P=0.06$; Figure 4$)$. Interestingly, no quarters, regardless of treatment, had a TES of 1 at any time throughout the trial. Baseline prevalence of TES $<3$ was $78.77 \%(\mathrm{PD})$ and $79.88 \%$ (ID), at $24 \mathrm{~d}$ these values were 82.11 and $83.29 \%$, and at the conclusion of the trial these values were 75.36 and $83.14 \%$.

At the beginning of trial 859 quarters had no growth on aerobic culture, whereas 224 had a mastitis pathogen identified on culture, an additional 234 samples were classified as "no significant growth," and 4 were contaminated. These numbers were $741,230,346$, and 4 at the conclusion of the trial (Table 4). Use of PD resulted in a greater risk for developing a new IMI, based on bacteriological culture, at the conclusion of the trial, as compared with ID (relative risk $=1.51$; CI $=1.10-2.07 ; P<0.05)$. Use of $\mathrm{PD}$ resulted in a greater risk, as compared with ID, of CNS (relative risk $=1.51$; CI: $1.10-2.25 ; P<0.05)$ present at the conclusion of the trial. Additionally, use of PD resulted in a greater risk of having Staph. aureus (relative risk $=2.30$; CI: 1.04-5.07; $P=0.03$ ) present at the conclusion of the trial. There was no difference in the number or relative risk for gram-negative pathogens or Streptococcus organisms in this trial.

Clinical mastitis during the trial was low; only 12 cows $(\mathrm{PD}=6, \mathrm{ID}=6)$ had a clinical mastitis event. No statistical analysis was performed on these data given the low incidence.

\section{DISCUSSION}

A limitation of this trial was that it was conducted on one farm. This is similar to other studies that have evaluated a powdered teat dip (Goldberg et al., 1994; Knutson et al., 2011). The farm used for the current trial was selected for similar reasons as the farm used in the Goldberg et al. (1994) trial: All animals had a visible identification tag, managers agreed to follow milking procedures as described in the Materials and Methods, and equipment was routinely evaluated. Sample size was lower than that in the Goldberg et al. (1994) trial ( $\mathrm{n}=509$ cows) but greater than that in the Knutson et al. (2011) trial $(\mathrm{n}=246$ cows $)$. A

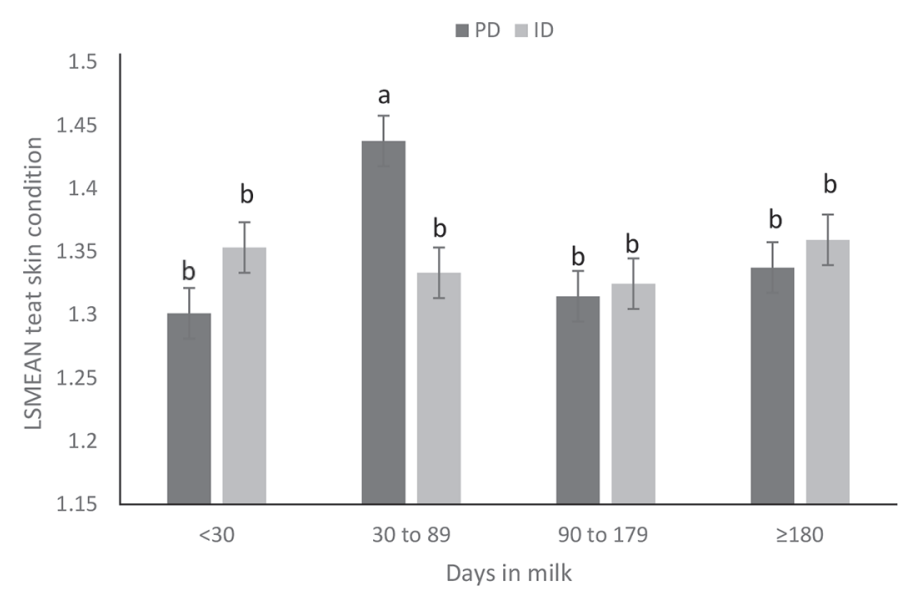

Figure 1. Final LSM for teat skin condition by treatment $(\mathrm{PD}=$ powdered, $0.5 \%$ chlorhexidine acetate-based postmilking teat dip; ID $=1 \%$ iodine-based, foamed, postmilking teat dip) and stage of lactation. ${ }^{\mathrm{a}, \mathrm{b}}$ Means with different letters differ $(P<0.05)$. SE $=0.019$. 
Table 3. Least squares means for linear score, teat skin condition, and teat end score by treatment, stage of lactation, and lactation number

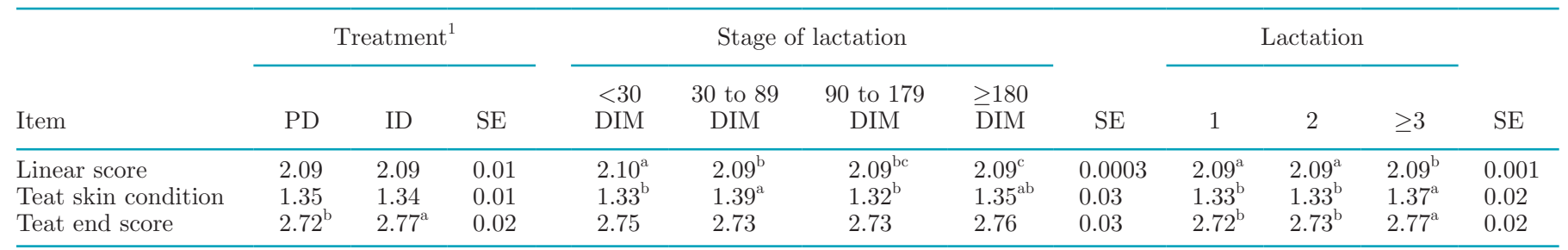

${ }^{\mathrm{a}-\mathrm{c}}$ Means within a row with different superscripts differ $(P<0.05)$.

${ }^{1} \mathrm{PD}=$ powdered chlorhexidine postdip; ID = foamed iodine-based postdip

post hoc power analysis was conducted on all results. Treatment differences for LS, TSC, and TES means all had $\geq 0.99$ power. Dichotomous bacteriological data (risk of bacterial growth, CNS, and Staph. aureus) had 84.3, 93.6, and $56.1 \%$ power. Based on incidence rates in this trial, a sample size of $\mathrm{n}=2,334$ would be needed to get $80 \%$ power to evaluate a difference in new Staph. aureus infections. We feel that this sample size provides strong data for LS, TSC, and TES, it also supports the findings reported by Goldberg et al. (1994) with regard to the bacteriological data, specifically Staph. aureus.

While barn temperature was moderate, outdoor temperature was similar to that reported by Knutson et al. (2011) and slightly cooler than that reported by Goldberg et al. (1994).

Application of teat dip may exacerbate teat skin chapping during cold, wet, and windy conditions (Fox and Norell, 1994). Changes in TSC associated with harsh weather or chemical irritation may take a few days or weeks to develop (Mein et al., 2001). Chapped teat skin is more susceptible to colonization by Staph. aureus (Fox et al., 1991), leading to an increased risk in occurrence of new IMI (Neave et al., 1969). When evaluating postmilking teat dips in colder climates, it

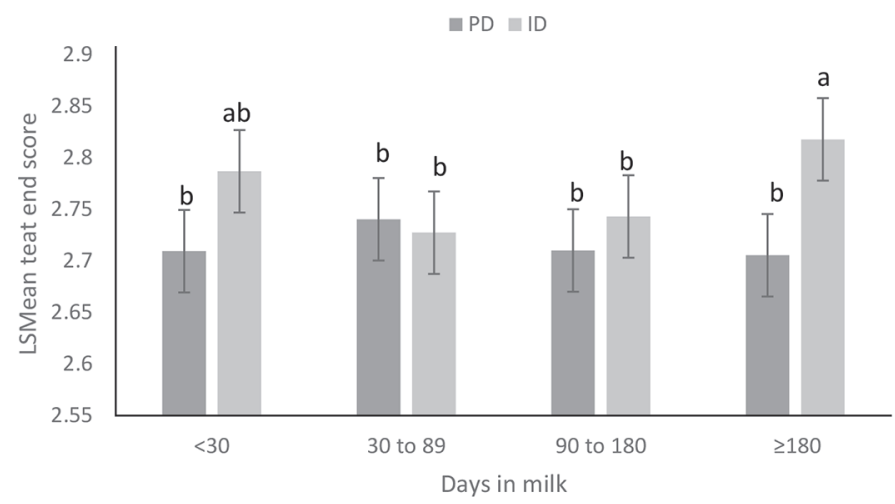

Figure 2. Least squares means teat end score at the conclusion of the study for treatment $(\mathrm{PD}=$ powdered, $0.5 \%$ chlorhexidine acetatebased postmilking teat dip; ID $=1 \%$ iodine-based, foamed, postmilking teat dip) by stage of lactation. ${ }^{\mathrm{a}, \mathrm{b}}$ Means with different letters differ $(P<0.05) . \mathrm{SE}=0.042$. is important to evaluate their effect on both TSC, and new IMI.

Goldberg et al. (1994) and Knutson et al. (2011) both reported changes in TSC. Knutson et al. (2011) reported that all cows, regardless of treatment, saw a decrease in TSC throughout the duration of the trial. Goldberg et al. (1994) reported that TSC improved among primiparous but not multiparous cows when a powdered teat dip was used. Both of these studies were conducted over a longer period of time (63 and $96 \mathrm{~d}$ ) as compared with the shorter duration of our trial (44 d). Another difference when comparing these studies is that we used a 3-point scale for TSC, whereas both of the aforementioned studies used a 5-point scale. The 3 -point scale used in this trial was simplified from the 5 -point scale to focus primarily on skin dryness (NMC, 2007). A TSC score of 3,4 , or 5 would be classified as a 3 on the 3 -point scale used in the present trial. Baseline prevalence of $\mathrm{TSC}=1$ and TES $<3$ was lower than that reported by Knutson et al., 2011 [>95\% (powdered and liquid treatments), $91 \%$ (liquid), and $81 \%$ (powdered), respectively].

Teat end scoring in this trial was based off a 5-point scale previously described by Goldberg et al. (1994).

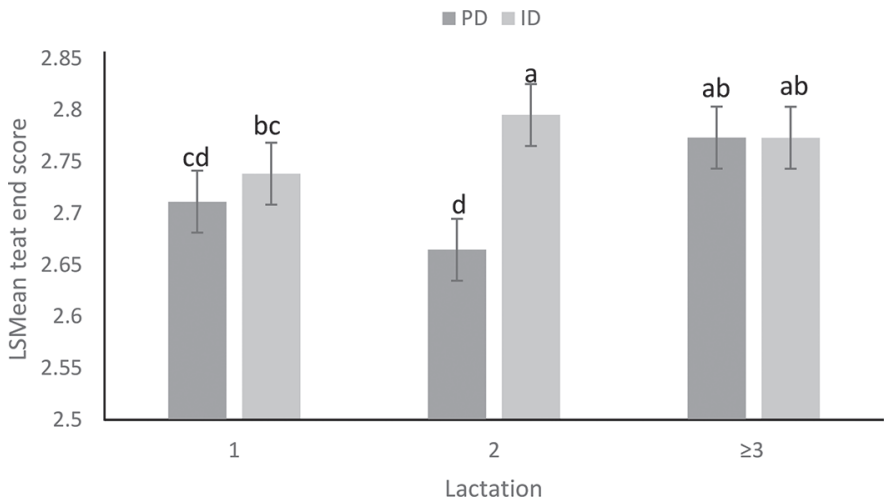

Figure 3. Least squares means teat end scores at the conclusion of study for treatment $(\mathrm{PD}=$ powdered, $0.5 \%$ chlorhexidine acetatebased postmilking teat dip; ID $=1 \%$ iodine-based, foamed, postmilking teat dip) by lactation number. ${ }^{\mathrm{a}-\mathrm{d}}$ Means different letters differ $(P$ $<0.05)$. SE $=0.027$. 


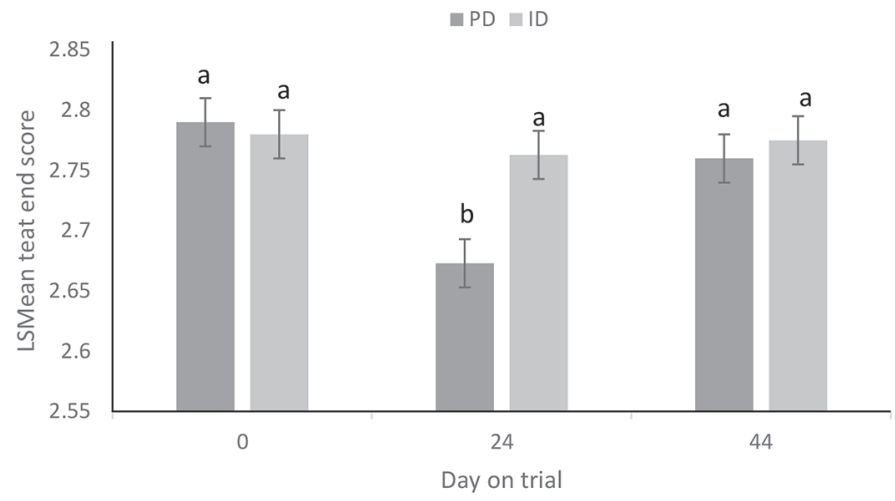

Figure 4. Least squares means teat end score at the conclusion of the study by treatment $(\mathrm{PD}=$ powdered, $0.5 \%$ chlorhexidine acetatebased postmilking teat dip; ID $=1 \%$ iodine-based, foamed, postmilking teat dip) and days on trial. ${ }^{\mathrm{a}, \mathrm{b}}$ Means with different letters differ $(P$ $<0.05)$. SE $=0.019$.

Similar to Goldberg et al. (1994) at the termination of the current trial, PD cows had a lower TES compared with ID cows. Unlike the Goldberg et al. (1994) trial, which observed that primiparous cows and multiparous cows receiving a powdered teat dip had a lower TES at the termination of the trial compared with cows receiving an iodine-based teat dip, we observed that 1st and $\geq 3$ rd lactation cows had similar TES at the termination of the trial, regardless of treatment. However, 2nd lactation cows on the ID treatment had a higher TES than 2nd lactation PD cows at the termination of the trial. While TES improved (decreased) at $24 \mathrm{~d}$ for PD cows, TES was similar at the start (d 0$)$ and termination (d 44) of the trial for both PD and ID treatment groups (Figure 3). Knutson et al. (2011) also reported no changes in TES from start to termination.

Similar to Goldberg et al. (1994), PD increased the risk of Staph. aureus and CNS compared with an iodinebased postmilking teat dip. It is important to note that only 27 quarters were positive for Staph. aureus $(\mathrm{PD}=$ $18, \mathrm{ID}=9)$ at the end of the trial. This is a very small number, and relative risk of new IMI may be different in herds with a higher incidence rate of Staph. aureus.

The use of foam postmilking teat dips reduces the amount of water on the teat compared with a conventional dip or spray and would in turn reduce the risk of freezing teat ends. However, use of a foamed product also reduces the amount of chemical, thus potentially increasing the risk of new IMI and poorer TSC due to lower amount of disinfectant and skin conditioners present. Foamed and liquid postmilking teat dips should have a similar performance for teat coverage if the proper dipper is used and the dip covers the entire surface of the teat. No conclusions can be made from the data presented in this paper as to the efficacy of a dip cup with liquid postmilking teat dip, a foamed

Table 4. Number of quarter samples that were positive and negative for bacterial growth at the start and conclusion of the trial

\begin{tabular}{|c|c|c|c|c|c|c|}
\hline \multirow[b]{2}{*}{ Etiology } & \multicolumn{3}{|c|}{ Initial sampling ${ }^{1}$} & \multicolumn{3}{|c|}{ Final sampling ${ }^{1}$} \\
\hline & $\begin{array}{c}\mathrm{PD} \\
(\mathrm{n}=615)\end{array}$ & $\begin{array}{c}\text { ID } \\
(\mathrm{n}=706)\end{array}$ & $\begin{array}{c}\text { Overall } \\
(\mathrm{n}=1,321)\end{array}$ & $\begin{array}{c}\mathrm{PD} \\
(\mathrm{n}=615)\end{array}$ & $\begin{array}{c}\text { ID } \\
(\mathrm{n}=706)\end{array}$ & $\begin{array}{c}\text { Overall } \\
(\mathrm{n}=1,321)\end{array}$ \\
\hline Bacterial growth & 102 & 122 & 224 & 129 & 101 & 230 \\
\hline \multicolumn{7}{|l|}{ Minor organism } \\
\hline Corynebacterium species & 1 & 0 & 1 & 1 & 0 & 1 \\
\hline $\mathrm{CNS}$ & 84 & 100 & 184 & 104 & 73 & 177 \\
\hline Gram-negative organism & & & 0 & & & \\
\hline Escherichia coli & 1 & 0 & 1 & 1 & 1 & 2 \\
\hline Klebsiella spp. & 0 & 0 & 0 & 2 & 6 & 8 \\
\hline Citrobacter spp. & 0 & 1 & 1 & 0 & 0 & 0 \\
\hline Enterobacter spp. & 0 & 1 & 1 & 2 & 1 & 3 \\
\hline Gram-negative bacillus & 9 & 10 & 19 & 0 & 3 & 3 \\
\hline Serratia sp. & 0 & 0 & 0 & 0 & 1 & 1 \\
\hline \multicolumn{7}{|l|}{ Streptococcus spp. } \\
\hline Enterococcus spp. & 2 & 2 & 4 & 0 & 3 & 3 \\
\hline Streptococcus spp. & 0 & 1 & 1 & 1 & 0 & 1 \\
\hline Strep. dysgalactiae & 0 & 0 & 0 & 0 & 1 & 1 \\
\hline Strep. uberis & 0 & 0 & 0 & 0 & 2 & 2 \\
\hline Lactococcus spp. & 0 & 0 & 0 & 0 & 1 & 1 \\
\hline Staphylococcus aureus & 5 & 7 & 12 & 18 & 9 & 27 \\
\hline Negative & 402 & 457 & 859 & 301 & 440 & 741 \\
\hline No significant growth ${ }^{2}$ & 109 & 125 & 234 & 182 & 164 & 346 \\
\hline Contaminated & 2 & 2 & 4 & 3 & 1 & 4 \\
\hline
\end{tabular}

${ }^{1}$ Treatments were $\mathrm{PD}=$ powdered chlorhexidine postdip; ID = foamed iodine-based postdip.

${ }^{2}$ No significant growth was defined as the sample having 1 nonpathogenic or $>2$ dissimilar nonpathogenic colony types present in low levels ( 1 to 5 colonies). 
postmilking teat dip or sprayer for postmilking teat dip, and their effect on teat health and milk quality during cold weather.

\section{CONCLUSIONS}

Use of PD increased the risk of an IMI being identified at the conclusion of the trial for CNS mastitis pathogen as compared with an iodine-based postmilking dip. While power was low, PD did increase the risk of Staph. aureus being identified at the conclusion of the trial. This may be a concern in herds with a high rate of Staph. aureus infection and should be evaluated with a larger sample size. Use of PD led to a lower TES as compared with ID. There was no treatment difference in LS, TSC, or subclinical mastitis (SCC $<200,000$ cells $/ \mathrm{mL}$ ). These results may differ if animals have greater exposure to outside elements or in herds with a different bacterial etiology. Additionally, temperature outside does not always reflect conditions inside the pens, future winter teat dip studies should include within pen temperature data as well as outside, ambient temperature.

\section{ACKNOWLEDGMENTS}

This research was funded by the Northern New York Agricultural Development Program. Derma Soft n’ Dry was donated by David Kerr (IBA Inc.)

\section{REFERENCES}

Blowey, R. W., and P. Edmondson. 2010. Mastitis in Dairy Herds. 2nded. CABI International, Wallingford, UK.

Breen, J. E., M. J. Green, and A. J. Bradley. 2009. Quarter and cow risk factors associated with the occurrence of clinical mastitis in dairy cows in the United Kingdom. J. Dairy Sci. 92:2551-2561. https://doi.org/10.3168/jds.2008-1369.

Burmeister, J. E., L. K. Fox, J. K. Hillers, and D. D. Hancock. 1998. Effects of premilking and postmilking teat disinfectants on teat skin condition. J. Dairy Sci. 81:1910-1916.

Ceballos-Marquez, A., T. Hemling, B. J. Rauch, M. Lopez-Benavides, and Y. H. Schukken. 2013. Noninferiority trial on the efficacy of premilking teat disinfectant against naturally occuring new intramammary infections using a novel 2-step diagnostic process. J. Dairy Sci. 96:8081-8092.

Dohoo, I. R., J. Smith, S. Andersen, D. F. Kelton, and S. Godden., and Mastitis Research Workers' Conference. 2011. Diagnosing intramammary infections: Evaluation of definitions based on a single milk sample. J. Dairy Sci. 94:250-261.

Faul, F., E. Erdfelder, A. G. Lang, and A. Buchner. 2007. G*Power 3: A flexible statistical power analysis program for the social, behavioral, and biomedical sciences. Behav. Res. Methods 39:175-191.

Fox, L. K., J. A. Nagy, J. K. Hillers, J. D. Cronrath, and D. A. Ratkowski. 1991. Effects of postmilking teat treatment on the colonization of Staphylococcus aureus in chapped teat skin. Am. J. Vet. Res. 52:799-802.

Fox, L. K., and R. J. Norell. 1994. Staphylococcus aureus colonization of teat skin as affected by postmilking teat treatment when exposed to cold and windy conditions. J. Dairy Sci. 77:2281-2288.
Goldberg, J. J., P. A. Murdough, A. B. Howard, P. A. Drechsler, J. W. Pankey, G. A. Ledbetter, L. L. Day, and J. D. Day. 1994 Winter evaluation of a postmilking powdered teat dip. J. Dairy Sci. $77: 748-758$.

Hemling, C. T. 2002. Teat condition-Prevention and cure through teat dips. Pages 1-14 in Proceedings of the British Mastitis Conference. Institute for Animal Health/Milk Development Council.

Hillerton, J. E., J. Cooper, and J. Morelli. 2007. Preventing bovine mastitis by a postmilking teat disinfectant containing acidified sodium chlorite. J. Dairy Sci. 90:1201-1208.

Hogan, J. S., D. M. Galton, R. J. Harmon, S. C. Nickerson, S. P. Oliver, and J. W. Pankey. 1990. Protocols for evaluating efficacy of post-milking teat dips. J. Dairy Sci. 73:2580-2585.

Knutson, K., L. L. Timms, M. G. Lopez Benavideg, M. Henderson, and T. Hemling. 2011. Evaluation of teat condition using liquid or powder dips in winter. Animal Industry Report: AS 657, ASL R2604. http://lib.dr.iastate.edu/ans_air/vol657/iss1/28.

Mein, G. A., F. Neijenhuis, W. F. Morgan, D. J. Reinemann, J. E. Hillerton, J. R. Baines, I. Ohnstad, M. D. Rasmussen, L. Timms, J. S. Britt, R. Farnsworth, N. Cook, and T. Hemling. 2001. Evaluation of bovine teat condition in commercial dairy herds: 1 . Noninfectious factors. Pages 347-351 in 2nd International Symposium on Mastitis and Milk Quality. Natl. Mastitis Counc. Inc., Madison, WI.

National Mastitis Council. 1999. Laboratory Handbook on Bovine Mastitis, Rev. ed. National Mastitis Council, Madison, WI.

National Mastitis Council. 2007. Guidelines for Evaluating Teat Skin Condition. National Mastitis Council. Verona, WI.

National Mastitis Council. 2014. Summary of peer-reviewed publications on efficacy of pre-milking and post-milking teat disinfectants published since 1980. Pages 245-258 in Natl. Mastitis Counc. Mtg. Proc., Orlando, FL. Natl. Mastitis Counc. Inc., Madison, WI.

Neave, F. K., F. H. Dodd, R. G. Kingwell, and D. R. Westgarth. 1969. Control of mastitis in the dairy herd by hygiene and management. J. Dairy Sci. 52:696-707.

Neijenhuis, F., H. W. Barkema, H. Hogeveen, and J. P. Noordhuizen. 2001. Relationship between teat-end callosity and occurrence of clinical mastitis. J. Dairy Sci. 84:2664-2672. https://doi.org/10 .3168/jds.S0022-0302(01)74720-0.

Oliver, S. P., B. E. Gillespie, M. J. Lewis, S. J. Ivey, R. A. Almeida, D. A. Luther, D. L. Johnson, K. C. Lamar, H. D. Moorehead, and H. H. Dowlen. 2001. Efficacy of a new premilking teat disinfectant containing a phenolic combination for the prevention of mastitis. J. Dairy Sci. 84:1545-1549.

Pankey, J. W., R. J. Eberhart, A. L. Cuming, R. D. Daggett, R. J. Farnsworth, and C. K. McDuff. 1984. Uptake on postmilking teat antisepsis. J. Dairy Sci. 67:1336-1353.

Reinemann, D. J., M. D. Rasmussen, S. LeMire, F. Neijenhuis, G. A. Mein, J. E. Hillerton, W. F. Morgan, L. Timms, N. Cook, R. Farnsworth, J. R. Baines, and T. Hemling. 2001. Evaluation of bovine teat condition in commercial dairy herds: 3 . Getting the numbers right. Pages 357-361 in Proceedings of the 2nd International Symposium on Mastitis and Milk Quality, NMC/AABP, Vancouver, Canada.

Ruegg, P. L. 2012. New perspectives in udder health management. Vet. Clin. North Am. Food Anim. Pract. 28:149-163.

Shook, G. E. 1993. Genetic improvement of mastitis through selection on somatic cell count. Vet. Clin. North Am. Food Anim. Pract. 9:563-581.

Vasquez, A. K., D. V. Nydam, M. B. Capel, S. Eicker, and P. D. Virkler. 2017. Clinical outcome comparison of immediate blanket treatment versus a delayed pathogen-based treatment protocol for clinical mastitis in a New York dairy herd. J. Dairy Sci. 100:2992-3003.

Vijaya Kumar, A., L. Venkateswara Rao, M. Kishan Kumar, B. Srinu, and T. Madhava Rao. 2012. Efficacy of udder disinfectants on reduction of bacterial load and certain pathogens of public health significance. J. Microbiol. Biotech. Res. 2:147-151. 